\title{
Increased tolerance to Phytophthora cinnamomi in offspring of ink-diseased chestnut (Castanea sativa Miller) trees
}

\author{
Álvaro Camisón ${ }^{1} \cdot$ M. Ángela Martín ${ }^{2} \cdot$ Jonàs Oliva $^{3,4} \cdot$ Malin Elfstrand $^{5} \cdot$ Alejandro Solla $^{1}$ \\ Received: 28 March 2019 / Accepted: 5 November 2019/Published online: 13 December 2019 \\ (C) INRA and Springer-Verlag France SAS, part of Springer Nature 2019
}

\begin{abstract}
- Key message Increased tolerance to Phytophthora cinnamomi was observed in small-sized offspring of ink-diseased chestnut trees, suggesting that a virulent pathogen can trigger a defence response of trees in the subsequent generation. Increased tolerance to water stress was not observed in offspring of chestnut trees.

- Context In sweet chestnut (Castanea sativa Miller), P. cinnamomi Rands is responsible for the widespread and destructive ink disease.

- Aims We investigated if the susceptibility of $C$. sativa to water stress and $P$. cinnamomi depends on the health status of mother trees.

- Methods Plants were grown from seeds collected from healthy and ink-diseased chestnut trees. Leaf wilting after drought exposure and plant mortality after pathogen inoculation were assessed.

- Results Offspring of ink-diseased trees had poorer performance in plant height and root biomass than offspring of healthy trees, with allocation of biomass to seeds mediating this effect. Leaf wilting due to water stress was similar in offspring of healthy and $P$. cinnamomi-infected trees. However, increased tolerance to P. cinnamomi was observed in small-sized seedlings, suggesting that tolerance in C. sativa may involve growth costs. This is the first report of increased tolerance to $P$. cinnamomi in plants germinating from a diseased tree.

- Conclusion The results suggest that an invasive pathogen can regulate the performance and prime a defence response of a forest tree species in the subsequent generation, and generate conflicting selection pressures related to plant size.
\end{abstract}

Keywords Tree regeneration $\cdot$ Maternal effects $\cdot$ Invasive pathogen $\cdot$ Priming $\cdot$ Stress memory

\section{Introduction}

Phytophthora cinnamomi Rands is responsible for ink disease in Castanea dentata (Marsh.) Borkh. (USA) and C. sativa Mill. (Atlantic areas of Europe), leading to extensive mortality of chestnut trees (Vettraino et al. 2005; Gonthier and Nicolotti

\section{Handling Editor: Cécile Robin}

Contribution of the co-authors $\mathrm{AC}$ did the analyses and measurements, MAM provided technical help, JO and ME helped with the transcriptome and AS designed the experiment.

Alejandro Solla

asolla@unex.es

Álvaro Camisón

alvarocc@unex.es

M. Ángela Martín

angela.martin@uco.es
2013; Jung et al. 2018). Infected chestnuts initially show small-sized chlorotic foliage, followed by defoliation and dieback, eventually resulting in whole crown dieback and tree mortality (Phillips and Burdekin 1982; Jung et al. 2018; Camisón et al. 2019). Symptoms are caused by extensive root loss and necrosis in the inner bark of main roots and collar.
Jonàs Oliva
jonas.oliva@pvcf.udl.cat
Malin Elfstrand
Malin.Elfstrand@slu.se

Extended author information available on the last page of the article 
Castanea sativa is a highly valued multipurpose tree native to Europe, where it covers 2.5 million ha, including cultivated orchards and wild forests with high biodiversity (Ciordia et al. 2012; Conedera et al. 2016). In Spain, it is probably the most culturally valued tree, but soils of nearly all $C$. sativa forests are infested by $P$. cinnamomi (Paloma Abad-Campos, unpublished results). The hybrid $P$. $\times$ cambivora, associated with ink disease in central and southeast Europe (Vettraino et al. 2005), has not been reported in Spain.

Long-term persistence of $C$. sativa depends on the success of tree regeneration. In areas where $P$. cinnamomi is present, it is likely that this invasive pathogen will modulate current and future forest dynamics of $C$. sativa forests. Chronic presence of Phytophthora spp. constrains tree regeneration at different stages, reducing seed production in infected mother trees, influencing seed germination and causing plant mortality in infested soils (Martín-García et al. 2015; Jung et al. 2018). Moreover, if exposed to drought, young $C$. sativa seedlings suffering root rot caused by Phytophthora spp. will probably be less competitive than non-susceptible species. In droughtprone areas of the Mediterranean basin such as southern and central Spain, climate change is causing temperature rise and water stress events in C. sativa stands (Ciordia et al. 2012; Camisón et al. 2020). Combined effects of infested soils and water deprivation could further limit the success of $C$. sativa regeneration in the understory. In this context, it is crucial to understand the differences in performance between offspring of weakened, infected mother trees and offspring of non-infected trees. Infections in the mother tree during seed development may alter the fitness of seedlings subjected to $P$. cinnamomi, water stress and other plant competitors.

The high genetic diversity in C. sativa (Martin et al. 2010; Cuestas et al. 2017; Martín et al. 2017), reflected in within- and among-population variation in traits of adaptive significance associated with tolerance to Phytophthora sp. (Robin et al. 2006; Santos et al. 2015; Alcaide et al. 2020) and water stress (Pliura and Eriksson 2002; Ciordia et al. 2012; Alcaide et al. 2019), suggests that the species is highly adaptable to environmental changes. Phenotypic plasticity for adaptation can also be achieved through transmitted maternal effects (Marshall and Uller 2007). Epigenetics is the study of heritable phenotypic changes that do not involve alterations in the DNA sequence. Maternal effects are a subcategory of transgenerational epigenetics and are defined as the influences of maternal environment, phenotype and/or genotype on offspring phenotypes, independently of the offspring genotypes (Ho 2014). Although the response of germination and seedling phenology to maternal temperatures has been studied in Pinus pinaster and Populus nigra (Zas et al. 2013; Dewan et al. 2018), the influence of the health status of forest trees on offspring has only been addressed in $P$. pinaster (Vivas et al. 2013, 2014a, 2014b). It was recently reported that maternal environments with low water availability produced
Eucalyptus seedlings with more efficient water use than maternal environments with high water availability (Vivas et al. 2019). Repeated exposure of trees to stress may cause transcriptional memory in a process known as 'priming' (D’Urso and Brickner 2017; Mauch-Mani et al. 2017). Transcriptional memory implies that stress-responsive genes are influenced by a stress experience and show differential expression in response to stress repetition. However, evidence for transgenerational passage of acquired resistance to stress is sparse (Avramova 2019).

We hypothesised that ink disease in $C$. sativa trees influences offspring performance and susceptibility to water stress and $P$. cinnamomi. The first objective of this study was to compare, in a common garden experiment, morphological traits of seedlings obtained from healthy mother trees with those of seedlings obtained from $P$. cinnamomi-infected mother trees. The second objective was to assess tolerance to water stress and P. cinnamomi in offspring of healthy and diseased mother trees. The third objective was to quantify expression of three genes related to ink-disease resistance (Cast_Gnk2-like, Cast_SAP11 and Cast_MYB44) in offspring of healthy and diseased mother trees in response to water stress and $P$. cinnamomi.

\section{Materials and methods}

\subsection{Plant material}

Plant material came from the $C$. sativa forest in Hervás, Extremadura region, southwest Spain $\left(40^{\circ} 15^{\prime} \mathrm{N}, 5^{\circ} 52^{\prime} \mathrm{W}\right.$; $805 \mathrm{~m}$ a.s.1.). The Hervás chestnut forest has a Mediterranean climate (MAT $=14.9{ }^{\circ} \mathrm{C} ; P=1004.7 \mathrm{~mm}$ ) and is currently threatened by severe drought episodes (e.g. total precipitation in 2015 and 2017 was 410 and $550 \mathrm{~mm}$, respectively) and the occurrence of several Phytophthora species, thus providing an ideal test-bed for studying global change factors affecting offspring (Pazianoto et al. 2019) . In October 2015, isolations from the rhizosphere of four healthy and four symptomatic trees (Fig. 1) suggested that symptomatic trees were infected by $P$. cinnamomi whereas no $P$. cinnamomi was detected in the soil under healthy trees. Occurrence of $P$. cinnamomi was assessed by taking fine roots and soil $2-3 \mathrm{~m}$ from the trunks, at depths of $10-40 \mathrm{~cm}$ from 2 cardinal points. Roots were plated on Petri dishes containing NARPH selective medium, and the soil was baited using leaflets of Quercus suber and Granny Smith apples, following conventional methods (Jung et al. 1996; Mora-Sala et al. 2018).

Three non-infected (asymptomatic) and three P. cinnamomiinfected (symptomatic) C. sativa trees were selected (Table 1). Trees were $>50 \mathrm{~m}$ apart to prevent healthy trees from sharing parts of their rhizosphere with infected trees. They were located close to a stream bank where soil and light conditions were 
Fig. 1 Healthy, non-infected (a) and symptomatic Phytophthora cinnamomi-infected (b) Castanea sativa trees used to assess biological performance of offspring. Hervás forest, Extremadura region, SW Spain
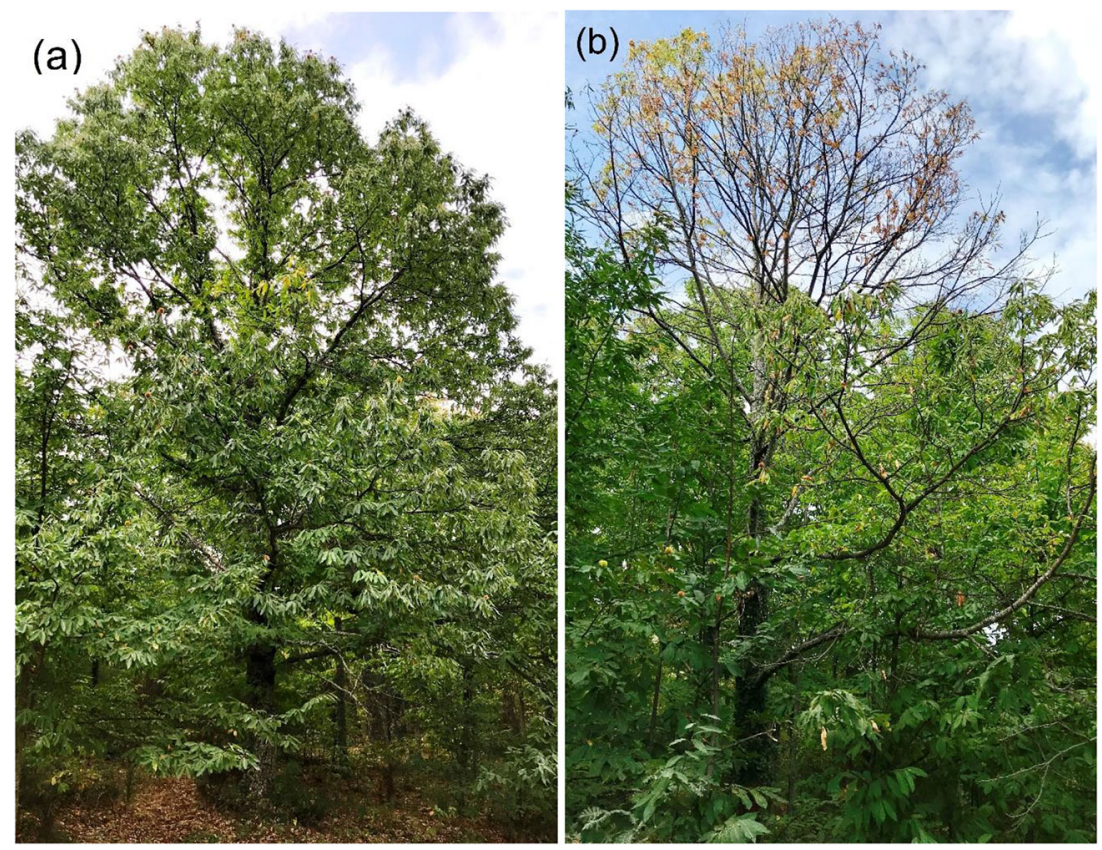

favourable for growth. Trees were $\sim 70$ years old and had similar height and basal diameter (ca. $20 \mathrm{~m}$ and $80 \mathrm{~cm}$, respectively). Infected trees showed typical symptoms of ink disease (Vettraino et al. 2005), including branch dieback, reduced shoot growth and reduced leaf and nut size (Table 1).

To determine whether offspring of healthy and $P$. cinnamomi-infected $C$. sativa trees have different biological performance when exposed to stress, a greenhouse experiment with 1-year-old seedlings was performed. The greenhouse is located at the Faculty of Forestry in Plasencia, University of Extremadura, Spain ( $40^{\circ} 02^{\prime} \mathrm{N}, 6^{\circ} 04^{\prime} \mathrm{W} ; 374 \mathrm{~m}$ a.s.l.). In November 2015, nuts from selected mother trees were hand collected from the ground and stored in a cold chamber at $4{ }^{\circ} \mathrm{C}$ for 2 weeks. Nuts were immersed in water to determine their viability and those that floated were discarded as non-viable. Viable seeds were immersed in a fungicide solution $\left(2 \mathrm{~g} \mathrm{~L}^{-1}\right.$ Thiram 80GD, ADAMA Inc., Spain) for $10 \mathrm{~min}$ and rinsed, then stratified in moistened blond peat (Pindstrup Mosebrug Inc., Spain) for 1 month at $4{ }^{\circ} \mathrm{C}$ (Soylu et al. 1999). Most seeds germinated during stratification.

\subsection{Experimental design and treatments}

In January 2016, stratification ended and nuts were individually sown in 48-cell rigid plastic root trainers (cells $330 \mathrm{~mL}$ in volume; $18 \mathrm{~cm}$ high, $5.3 \times 5.3 \mathrm{~cm}$ upper surface) containing sand
Table 1 Main characteristics of Castanea sativa mother trees free of Phytophthora cinnamomi infection (healthy) or infected with $P$. cinnamomi $(P c)$. Different lowercase letters indicate significant differences between values within trees, while different uppercase letters indicate significant differences between mean values within groups of trees according to their health status (ANOVA, $p<0.05)$

\begin{tabular}{|c|c|c|c|c|c|}
\hline Status & Mother tree & $\begin{array}{l}\text { Branch } \\
\operatorname{dieback}^{\mathrm{a}}(\%)\end{array}$ & $\begin{array}{l}\text { Current year shoot } \\
\text { growth }^{\mathrm{b}}(\mathrm{cm})\end{array}$ & $\begin{array}{l}\text { Leaf mass per area } \\
\left(\mathrm{g} \mathrm{cm}^{-2}\right)\end{array}$ & Seed weight ${ }^{d}(g)$ \\
\hline \multirow[t]{4}{*}{ Healthy } & 1 & 0 & 25.0 & 65.9 & $6.4 \pm 0.15 \mathrm{c}$ \\
\hline & 2 & 0 & 10.5 & 71.0 & $6.4 \pm 0.14 \mathrm{c}$ \\
\hline & 3 & 0 & 19.0 & 99.0 & $11.1 \pm 0.27 \mathrm{e}$ \\
\hline & Mean & $0.0 \mathrm{~A}$ & $18.2 \mathrm{~B}$ & $78.6 \mathrm{~B}$ & $7.9 \mathrm{~B}$ \\
\hline \multirow[t]{4}{*}{$P c$-infected } & 4 & 70 & 4.1 & 50.7 & $2.4 \pm 0.08 \mathrm{a}$ \\
\hline & 5 & 50 & 3.5 & 66.4 & $8.2 \pm 0.30 \mathrm{~d}$ \\
\hline & 6 & 40 & 1.8 & 71.5 & $4.3 \pm 0.20 \mathrm{~b}$ \\
\hline & Mean & $56.6 \mathrm{~B}$ & $3.1 \mathrm{~A}$ & $62.8 \mathrm{~A}$ & $4.9 \mathrm{~A}$ \\
\hline
\end{tabular}

${ }^{\text {a }}$ Percentage of dead branches visually estimated for each mother tree in October 2015

${ }^{\mathrm{b}}$ Measurements were carried out in October 2015 on four terminal shoots per mother tree (N, S, E and W sides of the tree) at approx. $2.5-\mathrm{m}$ height

${ }^{\mathrm{c}}$ Leaves from four terminal shoots per mother tree (N, S, E and $\mathrm{W}$ sides of the tree) at approx. 2.5-m height were oven dried at $60{ }^{\circ} \mathrm{C}$ for $48 \mathrm{~h}$ and weighed. Before drying, leaves were scanned $(n \sim 60)$

${ }^{\mathrm{d}}$ Individually assessed in 120 nuts per tree. Coefficients of variation in seed weight from healthy and $P c$-infected trees were 33.9 and $61.3 \%$, respectively 
and peat (1:3, pH 6). Earlier research by Cubera et al. (2012) showed that this pot size would provide oak seedlings with unrestricted root growth during treatments. Plants were arranged following a split-plot random design replicated in five blocks, with treatments acting as the main factor (three categories: control, water stress and P. cinnamomi infection; whole plots) and health status of mother trees as the split factor (two categories: asymptomatic and symptomatic, as shown in Fig. 1; split plots). In all five blocks, health status of mother trees was represented in each whole plot by eight individuals from each of the three mother trees selected. One block consisted of three root trainers, with each root trainer receiving a different treatment. Individuals were randomly positioned within each block and treatment. In total, 720 plants were distributed over 5 blocks $\times 3$ treatments $\times 2$ health statuses of mother trees $\times 3$ progenies $\times 8$ individuals. The term progeny will be further used to refer to half-sib plants sharing the same mother tree. Plants were kept in natural daylight under greenhouse shade that reduced solar radiation by $50 \%$ and hand watered to field capacity every 4 days until they were well established.

When plants were 5 months old and about $10 \mathrm{~cm}$ in height, five root trainers were left as controls, five were subjected to water stress and five were infested with P. cinnamomi. Water stress consisted of watering plants to field capacity every 10 days. The remaining plants were watered to field capacity 2 days per week. Soil moisture was checked in four cells per block and treatment using a TDR 100 soil moisture meter (Spectrum Technologies Inc., Plainfield, Illinois, USA) and 12-cm-length rods, and plant gas exchange was assessed using a portable differential infrared gas analyser (IRGA) (LCi, ADC Bio Scientific Ltd., UK) (Alcaide et al. 2019). Measurements confirmed significant differences in soil water content and stomatal conductance between control and water stressed plants (results not shown). Watering treatments lasted 1 month.

A single P. cinnamomi A2 strain isolated from roots of a Quercus ilex tree in Valverde de Mérida, SW Spain $\left(38^{\circ} 55^{\prime} \mathrm{N}\right.$, $6^{\circ} 11^{\prime} \mathrm{W}$; Corcobado et al. 2013), and highly virulent to seedlings of $Q$. ilex (Corcobado et al. 2017) and C. sativa was used. Inoculum was prepared following the procedure described by Jung et al. (1996). Briefly, a mix of $500 \mathrm{~cm}^{3}$ fine vermiculite, $40 \mathrm{~cm}^{3}$ oat grains and $350 \mathrm{ml}$ multivitamin juice broth $(200 \mathrm{~mL} / \mathrm{L}$ juice, $800 \mathrm{~mL} / \mathrm{L}$ distilled water with $3 \mathrm{~g} / \mathrm{L}$ $\mathrm{CaCO}_{3}$ ) was autoclaved twice in 1-L Erlenmeyer flasks. Individual plugs of $P$. cinnamomi were then added to the flasks containing the medium and incubated at $20{ }^{\circ} \mathrm{C}$ for 5 weeks. Soil was infested in May 2016, using a spoon to carefully mix $12 \mathrm{~mL}$ inoculum into the first $3 \mathrm{~cm}$ soil of each plant. After inoculation, plants were watered slightly and flooded the following day with chlorine-free water to stimulate sporangia production and zoospore release and spread. To prevent cross-contamination of plants within blocks, all root trainers were individually placed in large plastic boxes $(58 \mathrm{~cm} \times 38 \mathrm{~cm} \times 40 \mathrm{~cm}, 88 \mathrm{~L}$ in volume). In September 2016, P. cinnamomi was successfully re-isolated from root samples collected from inoculated plants only, following the method of Martín-García et al. (2015).

\subsection{Plant measurements and plant performance}

Nuts were individually weighed before sowing, and radicle length was individually measured in nuts starting to germinate ( $53.1 \%$ of total nuts). Radicle length was interpreted as a proxy of time to germinate, and short (if any) and long radicles were assumed to indicate late and early seed germination, respectively. Time to emerge of first leaves was assessed weekly. Plant height was measured before inoculation and at the end of the experiment, on 30 September 2016. After water stress treatment, the percentage of foliage showing wilting was visually estimated using a $5 \%$ interval. After inoculation treatment, plant mortality was assessed weekly for 2.5 months. At the end of the vegetative period in all control plants, height, stem diameter and biomass were assessed. Plants were destructively sampled and oven dried at $60{ }^{\circ} \mathrm{C}$ for $48 \mathrm{~h}$ and their above- and belowground biomass were determined. Roots were separated into fine (diameter $<2 \mathrm{~mm}$ ) and coarse (diameter $\geq 2 \mathrm{~mm}$ ) (Cubera et al. 2012), usually corresponding to secondary and tap roots, respectively. Before drying, leaves were scanned at $300 \times 300$ dpi resolution and the area of each leaf was determined using ImageJ 1.x software (Schneider et al. 2012). Leaf mass per area $\left(\mathrm{g} \mathrm{cm}^{-2}\right)$ was calculated for each seedling by dividing leaf dry weight by foliar area.

\subsection{Gene expression analysis}

We selected genes Cast_Gnk2-like, Cast_SAP11 and Cast_MYB44 for expression analysis because they have been reported to be associated with expression of resistance to P. cinnamomi in Castanea spp. and Castanea hybrids (Serrazina et al. 2015; Santos et al. 2017) (Table SM1). To compare gene expression in response to treatments, progenies from healthy mother trees (numbers 1 and 3 ) and from P. cinnamomi-infected mother trees (numbers 4 and 6) were selected at random and three seedlings per progeny and treatment were sampled. Gene expression analysis included 36 plants corresponding to 2 health status of mother trees $\times 2$ progenies $\times 3$ treatments (control, water stress and $P$. cinnamomi infection $) \times 3$ seedlings. Sampling times were chosen based on the literature (Serrazina et al. 2015; Redondo et al. 2015; Camisón et al. 2020). Samples were taken 15 days after water stress started and 2, 4 and 7 days after inoculation. About 3-4 fine roots per plant were excised, washed with water and immediately submerged in RNAlater ${ }^{\circledR}$ (R0901 - SigmaAldrich $®)$ to prevent RNA degradation. 
Total RNA was isolated using two modifications to the protocol developed by Chang et al. (1993): samples were incubated for $10 \mathrm{~min}$ instead of $15 \mathrm{~min}$, and one-third instead of one-fourth of volume of $\mathrm{LiCl} 8 \mathrm{M}$ was added, with a final concentration of $750 \mathrm{mM}$. RNA integrity and concentration were assessed by loading samples into an Agilent 2100 Bioanalyzer (Agilent Technologies, Inc.). cDNA synthesis was performed with an iScript cDNA Synthesis kit (Bio-Rad) using $200 \mathrm{ng}$ total RNA in a $20-\mu$ l total volume and incubating samples in a PCR thermocycler for $5 \mathrm{~min}$ at $25^{\circ} \mathrm{C}, 30 \mathrm{~min}$ at $42^{\circ} \mathrm{C}$ and $5 \mathrm{~min}$ at $85^{\circ} \mathrm{C}$. Primers for target genes and Actin-7, chosen as housekeeping gene (Table SM1), were designed with Primer 3 (Untergasser et al. 2012) and the following settings: product size $80-150 \mathrm{bp}$, primer size 18-25 bp, primer $\operatorname{Tm} 57-62^{\circ} \mathrm{C}$, primer GC content $40-60 \%$ and Max $3^{\prime}$ self complementarity 2 bases. Three technical replicates consisting of $20 \mu \mathrm{L}$ volume were used for each biological sample. Real-time PCR reactions were performed by mixing $1 \mu \mathrm{L}$ non-diluted template cDNA, $0.25 \mathrm{pM}$ of each primer and $1 \mathrm{X}$ SSoFast EvaGreen reaction mixture (Bio-Rad). For negative controls, $1 \mu \mathrm{L}$ nuclease-free water was used instead of template cDNA. Primer efficiency was assessed by including one standard curve for each gene in the assay. The PCR conditions were $2 \mathrm{~min}$ at $90{ }^{\circ} \mathrm{C}$ followed by 40 cycles of $5 \mathrm{~s}$ at $95{ }^{\circ} \mathrm{C}, 10 \mathrm{~s}$ at $60{ }^{\circ} \mathrm{C}$ for annealing and $30 \mathrm{~s}$ at $72{ }^{\circ} \mathrm{C}$. After amplification, melting curve analysis was carried out for each gene to check gene-specific amplification. Relative gene expression was calculated using the $\Delta \Delta \mathrm{CT}$ method (Livak and Schmittgen 2001).

\subsection{Statistical analysis}

Plant tolerance to water stress was assessed by comparing 'leaf wilting' (continuous variable indicating wilting intensity from 0 to $100 \%$ ) in offspring of healthy mother trees with 'leaf wilting' in offspring of ink-diseased mother trees. A linear mixed model was performed using 'leaf wilting' as the dependent variable, 'health status of mother tree', 'block' and 'health status of mother tree $\times$ block' as the fixed factors, 'mother tree' (nested within 'health status of mother tree') as a random factor, and 'seed weight', 'radicle length', 'time to emerge' and 'plant height' as covariates. Means of leaf wilting among progenies were compared using the linear mixed model.

Plant tolerance to $P$. cinnamomi was assessed by comparing 'time to death' (survival time since inoculation) in offspring of healthy mother trees with 'time to death' in offspring of ink-diseased mother trees. To analyse 'time to death' of plants and determine seedling survival probabilities, the Kaplan-Meier estimate was used (Solla et al. 2011). To test for statistical differences between survival probabilities of progenies, the log rank test was used.

Survival analysis does not account for the effect of continuous covariates on survival probabilities. A first approach to take 'plant height' into account consisted of dividing seedlings into offspring $1-10 \mathrm{~cm}$ tall from healthy mother trees $(n=23)$, offspring 1-10 cm tall from $P$. cinnamomi-infected mother trees $(n=43)$, offspring $>10 \mathrm{~cm}$ tall from healthy mother trees $(n=$ 54 ), and offspring $>10 \mathrm{~cm}$ tall from $P$. cinnamomi-infected mother trees $(n=41)$. A second approach to assess whether 'seed weight', 'radicle length', 'time to emerge' and 'plant height' covariates influenced offspring susceptibility to $P$. cinnamomi consisted in using a Cox proportional hazards model which was fitted to the survival data (Zhang 2016). Cox regression estimates how plant survival is affected by several effects relative to a control group (offspring of non-infected mother trees). The measure of effect is the hazard ratio, which is the risk of failure or the probability of suffering mortality. The effects 'health status of mother tree', 'seed weight', 'radicle length', 'time to emerge', 'plant height' and the interactions of these effects were included in the model. The autocorrelation between seedlings of the same mother tree was accounted for by estimating 'robust standard errors' for the model's coefficients. Automatic stepwise variable selection based on the Akaike information criterion was applied to identify the most relevant effects. The significance of the Cox model was evaluated by the likelihood ratio test and the Wald statistic, while the explanatory power of the model was evaluated using the C-statistic and $R^{2}$.

All data were checked for normality and homoscedasticity by applying the Shapiro-Wilk and Bartlett tests, respectively. Differences between means of phenotypic traits and 'seed weight' of mother trees (Table 1) were analysed by ANOVA. Fisher's least significant difference (LSD) was used in post hoc tests. To identify differences in gene expression either between offspring of healthy and $P$. cinnamomi-infected trees or between control and treated seedlings, the Mann-Whitney test was used. Relations between the early performance of seedlings and the time to death, parameters were examined using Pearson correlation coefficients within seedlings from healthy and $P$. cinnamomi-infected mother trees. All statistical analyses were performed in $\mathrm{R}$ software environment version 3.4.2 (R Foundation for Statistical Computing, http://www.R-project.org). Functions in the 'survival' version 2.41-3 (Therneau 2015) and 'survminer' version 0.4.0.999 (Kassambara and Kosinski 2017) packages were used for survival time analysis and optimal cut point calculations, respectively, and the 'agricolae' package was used for comparison of means between groups.

\section{Results}

\subsection{Plant performance in offspring of healthy and $P$. cinnamomi-infected trees}

Severe infection of adult $C$. sativa trees by $P$. cinnamomi did not delay or reduce seed germination rate (Table 2). However, 
offspring of healthy trees were significantly taller than offspring of $P$. cinnamomi-infected trees $(p<0.001$; Table 2$)$. The tallest and smallest progenies belonged to the mother trees with the heaviest and lightest seeds (Tables 1 and 2). At the end of the vegetative period, seedling performance was strongly influenced by health status of mother trees (Table 2).

Correlation analysis after merging data of plants from mother trees with the same health status showed that 'seed weight' was correlated to 'plant height', 'stem diameter' and woody biomass of $C$. sativa seedlings $(p<0.05$; Table 3$)$. Contrary to expectation, negative correlations between 'plant height' and 'radicle length' $(p<0.05)$ and positive correlations between 'plant height' and 'time to emerge' $(p<0.001)$ were observed, indicating that taller plants were obtained from seeds germinating and emerging late (Table 3 ). Most correlations were substantially conditioned by health status of mother tree (Table 3 ).

\subsection{Offspring response to water stress}

Unstressed control plants did not wilt. In response to water stress treatment, offspring of $P$. cinnamomi-infected trees wilted similar to offspring of healthy trees (16.7 vs $18.9 \%$; $p>0.05$; Table 2). According to the linear mixed model used, the only factors explaining variability in 'leaf wilting' were 'seed weight' $(F=9.1, p=0.002)$ and 'plant height' $(F=51.0$, $p<0.001$ ) (Table SM2). Pearson correlation analysis with values of all seedlings showed that 'leaf wilting' did not correlate to 'seed weight' but did correlate to 'time to emerge'

Table 2 Early performance traits $( \pm \mathrm{se})$ in Castanea sativa seedlings from healthy and Phytophthora cinnamomi $(P C)$-infected mother trees, and leaf wilting and mortality values after water stress and $P c$ treatments, respectively. Seedlings from the untreated control treatment did not wilt or die. Different lowercase letters indicate significant differences between
( $r=-0.14, p=0.011)$, 'plant height' $(r=-0.30 ; p<0.001)$, 'biomass of fine roots' $(r=-0.25, p<0.01)$ and 'biomass of tap roots' $(r=-0.15 ; p<0.05)$.

\subsection{Offspring response to $P$. cinnamomi}

Plant mortality due to $P$. cinnamomi was similar in offspring of healthy and P. cinnamomi-infected trees (Fig. 2a, Table 2). However, the group of plants $1-10 \mathrm{~cm}$ tall from $P$. cinnamomiinfected trees died less and more slowly than the other groups of plants (Fig. 2b). Cox proportional hazards model $\left(p<0.001, R^{2}=0.13\right.$, concordance $\left.=63.6 \%\right)$ showed that the risk of plants dying on inoculation was significantly influenced by 'health status of mother tree' (if infected by $P$. cinnamomi), 'radicle length' and the 'health status of mother tree (if infected by $P$. cinnamomi) $\times$ plant height' interaction (Table 4). Offspring had on average $85 \%$ lower risk of dying if germinated from $P$. cinnamomi-infected instead of from healthy mother trees. A $1 \mathrm{~mm}$ increase in radicle length increased the daily probabilities of death in offspring of both healthy and $P$. cinnamomi-infected trees by $3 \%$. The Cox model predicted survival probabilities of $52 \%$ for short and $22 \%$ for tall offspring from P. cinnamomiinfected trees, and $22 \%$ for short and $28 \%$ for tall offspring from healthy trees.

Higher variability in response to $P$. cinnamomi was observed in offspring of $P$. cinnamomi-infected trees than in offspring of healthy trees. Pearson correlation analysis

values within progenies, while different uppercase letters indicate significant differences between mean values within groups of progenies according to the health status of their mother trees (linear mixed model, $p<0.05)$

\begin{tabular}{|c|c|c|c|c|c|c|c|c|c|}
\hline \multicolumn{2}{|l|}{ Mother tree } & \multicolumn{3}{|c|}{ Offspring $(n \approx 120)$} & \multicolumn{3}{|c|}{ Control treatment $(n \approx 40)$} & \multirow{2}{*}{$\begin{array}{l}\text { Water stress } \\
\text { treatment } \\
(n \approx 40) \\
\text { Leaf wilting }{ }^{\mathrm{c}} \\
(\%)\end{array}$} & \multirow{2}{*}{$\begin{array}{l}P c \text { treatment } \\
(n \approx 40) \\
\text { Plant mortality }{ }^{\mathrm{d}}(\%)\end{array}$} \\
\hline Status & \# & $\begin{array}{l}\text { Germination } \\
\text { rate }(\%)\end{array}$ & $\begin{array}{l}\text { Time to } \\
\text { emerge } \\
\text { (days) }\end{array}$ & $\begin{array}{l}\text { Plant } \\
\text { height }^{\mathrm{a}} \\
(\mathrm{cm})\end{array}$ & $\begin{array}{l}\text { Woody } \\
\text { biomass }^{\text {b }} \\
(\mathrm{g})\end{array}$ & $\begin{array}{l}\text { Fine root } \\
\text { biomass }^{\mathrm{b}}(\mathrm{g})\end{array}$ & $\begin{array}{l}\text { Leaf mass } \\
\text { per area } \\
\left(\mathrm{g} \mathrm{m}^{-2}\right)\end{array}$ & & \\
\hline \multirow[t]{4}{*}{ Healthy } & 1 & 83 & $41 \pm 2.3 b$ & $10.1 \pm 0.4 b$ & $1.9 \pm 0.17 b$ & $0.32 \pm 0.21 \mathrm{~b}$ & $8.02 \pm 0.52 b$ & $13.7 \pm 4.0 \mathrm{a}$ & 80 \\
\hline & 2 & 58 & $36 \pm 3.3 b$ & $8.7 \pm 0.6 b$ & $2.0 \pm 0.23 b$ & $0.24 \pm 0.15 \mathrm{ab}$ & $7.41 \pm 0.42 \mathrm{ab}$ & $34.4 \pm 8.7 b$ & 75 \\
\hline & 3 & 82 & $40 \pm 3.6 b$ & $12.5 \pm 0.5 \mathrm{c}$ & $2.5 \pm 0.21 \mathrm{~b}$ & $0.30 \pm 0.18 b$ & $7.50 \pm 0.35 \mathrm{ab}$ & $17.3 \pm 3.9 \mathrm{ab}$ & 78 \\
\hline & Mean & $75 \mathrm{~A}$ & $39 \mathrm{~A}$ & $10.1 \mathrm{~B}$ & $2.1 \mathrm{~B}$ & $0.29 \mathrm{~B}$ & $7.6 \mathrm{~B}$ & $18.9 \mathrm{~A}$ & $78 \mathrm{~A}$ \\
\hline \multirow[t]{4}{*}{$P c$-infected } & 4 & 93 & $24 \pm 1.3 \mathrm{a}$ & $5.9 \pm 0.2 \mathrm{a}$ & $1.2 \pm 0.09 \mathrm{a}$ & $0.17 \pm 0.09 \mathrm{a}$ & $6.27 \pm 0.19 \mathrm{a}$ & $16.5 \pm 3.8 \mathrm{ab}$ & 76 \\
\hline & 5 & 83 & $39 \pm 2.4 b$ & $10.1 \pm 0.5 b$ & $2.0 \pm 0.22 b$ & $0.26 \pm 0.19 \mathrm{ab}$ & $7.38 \pm 0.43 \mathrm{ab}$ & $20.2 \pm 4.8 \mathrm{ab}$ & 75 \\
\hline & 6 & 50 & $50 \pm 5.0 \mathrm{~b}$ & $8.7 \pm 0.6 b$ & $1.2 \pm 0.21 \mathrm{a}$ & $0.21 \pm 0.12 \mathrm{ab}$ & $7.53 \pm 0.45 \mathrm{ab}$ & $10.7 \pm 4.9 \mathrm{a}$ & 60 \\
\hline & Mean & $75 \mathrm{~A}$ & $35 \mathrm{~A}$ & $7.9 \mathrm{~A}$ & $1.4 \mathrm{~A}$ & $0.21 \mathrm{~A}$ & $6.7 \mathrm{~A}$ & $16.7 \mathrm{~A}$ & $71 \mathrm{~A}$ \\
\hline
\end{tabular}

${ }^{\text {a }}$ Measured before treatments. Significantly related to stem diameter $(r=0.68, p<0.001$; data not shown)

${ }^{\mathrm{b}}$ Assessed in untreated plants at the end of the vegetative period

${ }^{c}$ Assessed 1 month after water stressed treatment started

${ }^{\mathrm{d}}$ Assessed 2.5 months after inoculation 
Table 3 Pearson values from individual correlations among early performance variables in Castanea sativa seedlings from healthy (above the diagonal) and Phytophthora cinnamomi-infected (below the diagonal) mother trees. Asterisks indicate levels of significance at $* p<0.05$, $* * p<0.01$ and $* * * p<0.001 ;$ ns $=$ not significant

Seed weight Radicle length Time to emerge Plant height Woody biomass Taproot biomass Fine root Leaf mass

\begin{tabular}{|c|c|c|c|c|c|c|c|c|}
\hline Seed weight & $\mathrm{X}$ & ns & ns & $0.42 * * *$ & $0.53 * * *$ & $0.46^{* * *}$ & ns & ns \\
\hline Radicle length & $-0.28 * *$ & $\mathrm{X}$ & $-0.23 * *$ & $-0.26^{* *}$ & ns & ns & ns & ns \\
\hline Time to emerge & $0.21 * *$ & $-0.56^{* * *}$ & $\mathrm{X}$ & $0.29 * * *$ & ns & ns & ns & ns \\
\hline Plant height & $0.50 * * *$ & $-0.35^{* * *}$ & $0.28 * * *$ & $\mathrm{X}$ & $0.38 * *$ & ns & ns & ns \\
\hline Woody biomass & $0.60 * * *$ & $\mathrm{~ns}$ & ns & $0.69 * * *$ & $\mathrm{X}$ & $0.90 * * *$ & $0.24 *$ & ns \\
\hline Taproot biomass & $0.60 * * *$ & $\mathrm{~ns}$ & ns & $0.59 * * *$ & $0.94 * * *$ & $\mathrm{X}$ & $0.25 *$ & ns \\
\hline Fine root biomass & $0.35 * *$ & $\mathrm{~ns}$ & ns & $0.49 * * *$ & $0.62 * * *$ & $0.59 * * *$ & $\mathrm{X}$ & ns \\
\hline Leaf mass per area & $0.47 *$ & $-0.38^{*}$ & ns & ns & $0.46^{*}$ & $0.47 *$ & $0.40 *$ & $\mathrm{X}$ \\
\hline
\end{tabular}

confirmed the negative relation between 'time to death' and 'radicle length' in both groups of offspring $(p<0.05)$. In offspring of $P$. cinnamomi-infected trees only (Fig. 3), 'time to death' was related to 'plant height' $(r=-0.19, p=0.002)$.

\subsection{Gene expression}

In response to water stress treatment, no significant differences of gene expression between offspring of healthy and
P. cinnamomi-infected mother trees were observed (results not shown). At day 15 after water stress had started, only gene Cast_SAP11 was significantly more expressed in water stressed than in control plants (5.2- vs 0.3-fold, respectively, $p=0.0021$, $t$ test).

Gene expression was constant over time in non-inoculated control plants (Fig. 4). Two days after inoculation (dai), gene expression did not differ between control and inoculated plants (Fig. 4). At four and seven dai, the Cast_Gnk2-like gene
Fig. 2 Estimated survival probabilities of Castanea sativa seedlings after Phytophthora cinnamomi inoculations considering health status of mother trees (a) and both health status of mother trees and seedling height (b) as grouping variables. Seedlings germinated from healthy and Phytophthora cinnamomi $(P C)$-infected mother trees. A $p$ value is provided for the global log rank test, with different letters indicating significant differences between survival curves $(p<0.05)$ according to the $\log$ rank test
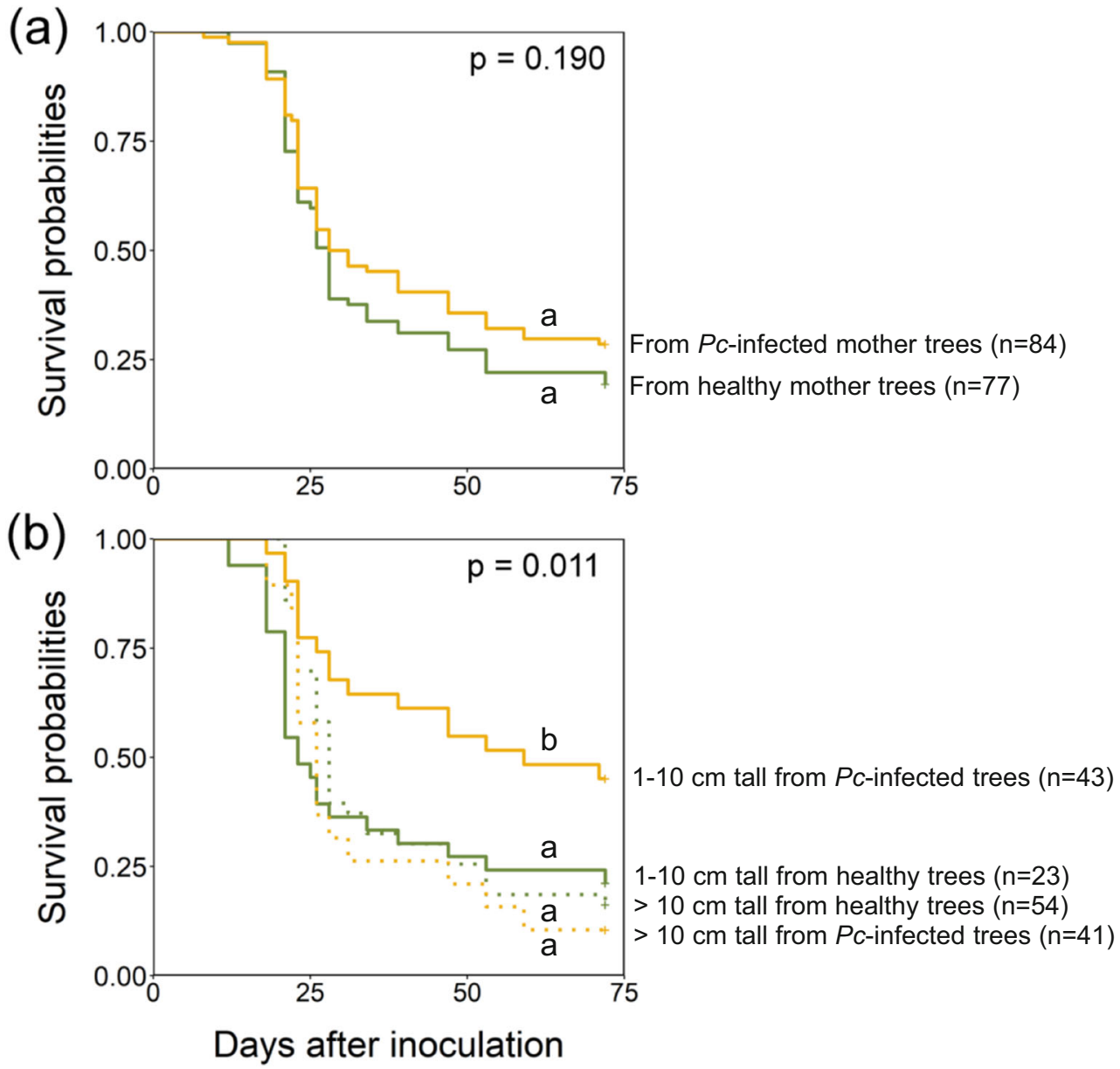
Table 4 Parameters of the Cox regression model used to analyse Castanea sativa trees after artificial inoculations with Phytophthora cinnamomi. The reference group was the offspring of healthy mother trees. Likelihood ratio test $(7 \mathrm{df})=$ $21.79 ; p=0.0013$ survival data in the offspring of

\begin{tabular}{lcclrr}
\hline Effect & Estimate & $\begin{array}{l}\text { Hazard ratio } \\
( \pm \text { robust SE })\end{array}$ & $\begin{array}{l}95 \% \text { confidence } \\
\text { interval }\end{array}$ & $Z$ score & $p$ value \\
\hline $\begin{array}{l}\text { Health status of mother tree } \\
\quad P c \text {-infected })\end{array}$ & -1.78 & $0.15 \pm 0.53$ & $0.05,0.44$ & -3.47 & $<0.001$ \\
$\begin{array}{l}\text { Seed weight } \\
\text { Radicle length }\end{array}$ & -0.00 & $0.99 \pm 0.01$ & $0.93,1.03$ & -0.24 & 0.816 \\
$\begin{array}{l}\text { Time to emerge } \\
\text { Plant height }\end{array}$ & 0.03 & $1.03 \pm 0.00$ & $1.02,1.04$ & 4.93 & $<0.001$ \\
$\begin{array}{l}\text { Health status of mother tree } \\
\quad(P c \text {-infected }) \times \text { plant height }\end{array}$ & 0.00 & $1.00 \pm 0.00$ & $0.99,1.01$ & 0.92 & 0.352 \\
$\begin{array}{l}\text { Health status of mother tree } \\
\quad(\text { healthy }) \times \text { plant height }\end{array}$ & -0.02 & $0.97 \pm 0.03$ & $0.91,1.03$ & -0.84 & 0.390 \\
\hline
\end{tabular}

${ }^{\text {a }}$ The only significant interaction

${ }^{\mathrm{b}}$ Non-significant values or ratios $=1$ indicate no effect on plant survival; significant ratios $<1$ indicate plant survival increases due to the effect; significant ratios $>1$ indicate plant survival decreases due to the effect. The effect of a variable on plant survival (\%) in relation to the reference group can be obtained as ( 1 - hazard ratio) $\times$ 100

was more expressed in inoculated plants than in controls (Fig. 5a). Expression levels of Cast_SAP11 peaked at four dai in inoculated plants (Fig. 5b) and Cast_MYB44 was not regulated in response to $P$. cinnamomi (Fig. $5 \mathrm{c}$ ). No significant differences were observed in gene expression between
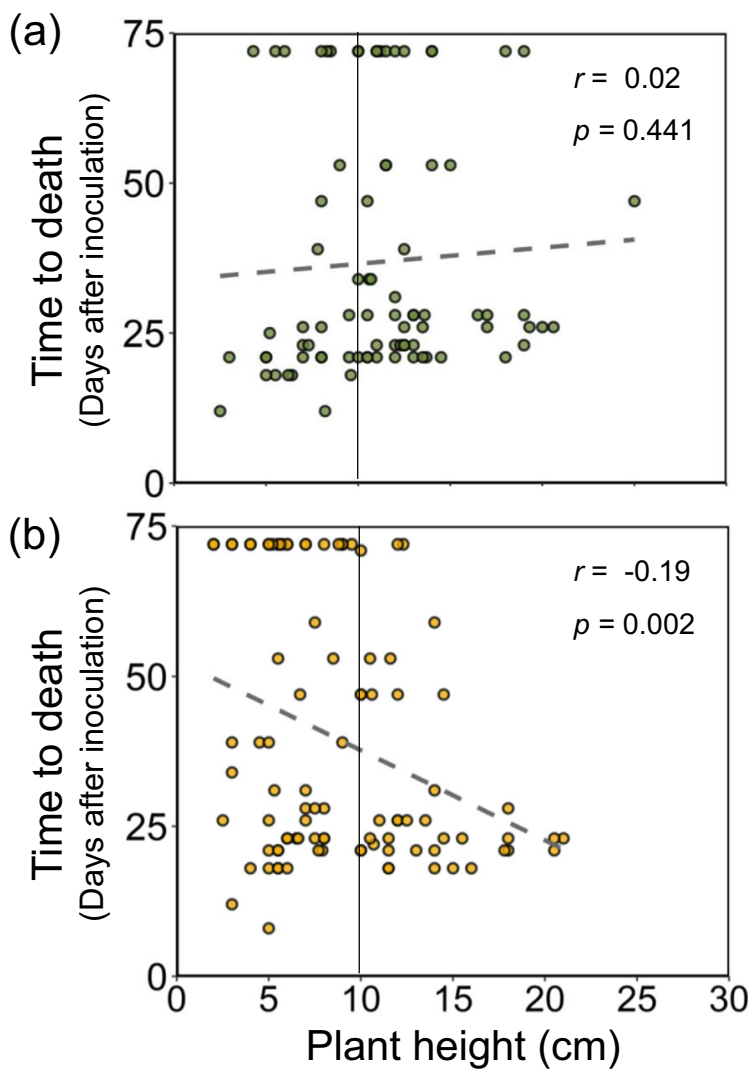

Fig. 3 Relations between 'time to death' and 'plant height' of Castanea sativa seedlings after Phytophthora cinnamomi inoculations in offspring of healthy, non-infected (a) and symptomatic P. cinnamomi-infected (b) mother trees. Vertical lines separate seedlings $1-10 \mathrm{~cm}$ tall from seedlings $>10 \mathrm{~cm}$ tall offspring of healthy and P. cinnamomi-infected mother trees (Fig. 5).

\section{Discussion}

\subsection{Seed weight and offspring of ink-diseased chestnuts}

The performance of young trees is genetically determined, but also can be altered by hardening practices (Villar-Salvador et al. 2012) and unfavourable scenarios experienced by the mother trees (Vivas et al. 2013, 2014a, 2014b). The present study shows that $P$. cinnamomi infection of chestnuts inhibits early growth of offspring. It also confirms that plant growth inhibition is mediated by seed size-dependent mechanisms, probably involving allocation of biomass to seeds (i.e. seed provisioning) (Shi et al. 2019). The morphological traits most affected were plant height and root biomass. In several studies, including this one, plant height and root biomass were directly dependent on seed mass (Çiçek and Tilki 2007; RamírezValiente et al. 2009) and seed mass was directly influenced by environmental factors experienced by mother trees (Vivas et al. 2013). Large seedlings are better able to acquire and retain resources than their smaller counterparts, therefore enhancing survival chances, growth, and reproductive opportunities and success (Ramírez-Valiente et al. 2009; Younginger et al. 2017).

Seed size variability, found to be higher in Phytophthorainfected than in healthy mother trees, was also higher in mother trees of $P$. pinaster growing under unfavourable than under favourable conditions (Zas et al. 2013). The high variation in traits in the offspring of $P$. cinnamomi-infected mother trees may be a consequence of the high and significant variation in 
(a)

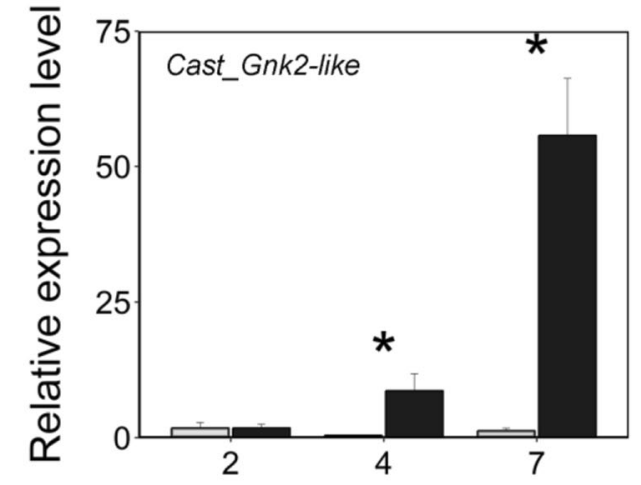

(b)

Days after inoculation

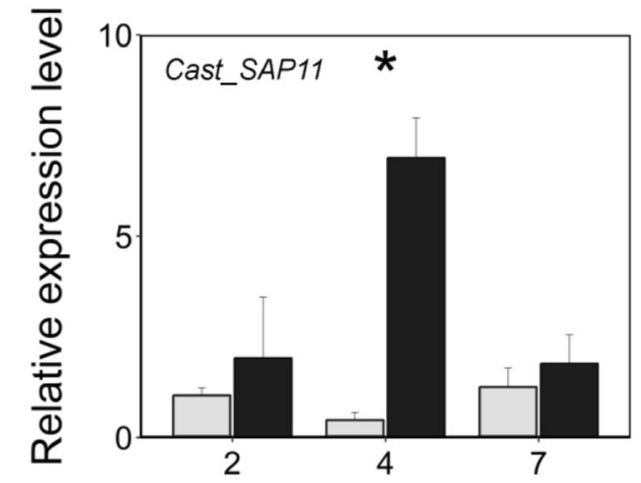

(c)

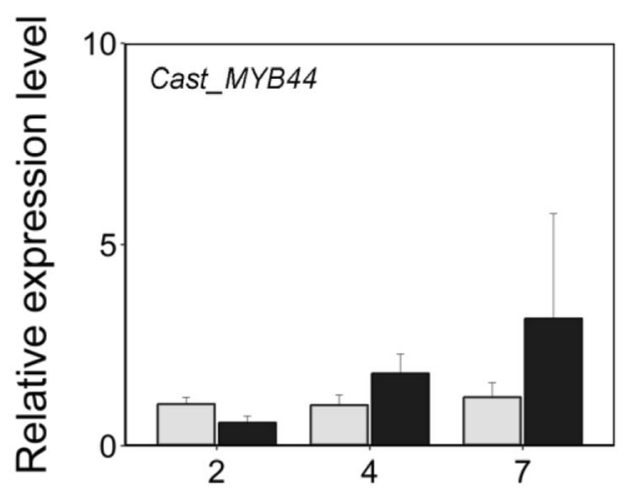

Days after inoculation

Fig. 4 Relative expression of Cast_Gnk2-like (a), Cast_SAP11 (b) and Cast_MYB44 (c) genes in offspring of Castanea sativa not inoculated (white bars) and inoculated (black bars) with Phytophthora cinnamomi ( $n=3$ plants). Observe differences in scale. Asterisks indicate significant differences $(p<0.05)$ between mean values on the same date

traits in infected mother trees. Increased seed size variability could be considered an adaptive response because a wide range of phenotypes is produced in a given unfavourable environment. However, the low variability in seed size and other traits in offspring of the most symptomatic chestnut (tree 4, smallest seeds) suggests inability to adapt (Kleunen and Fischer 2005) and few chances for competition and

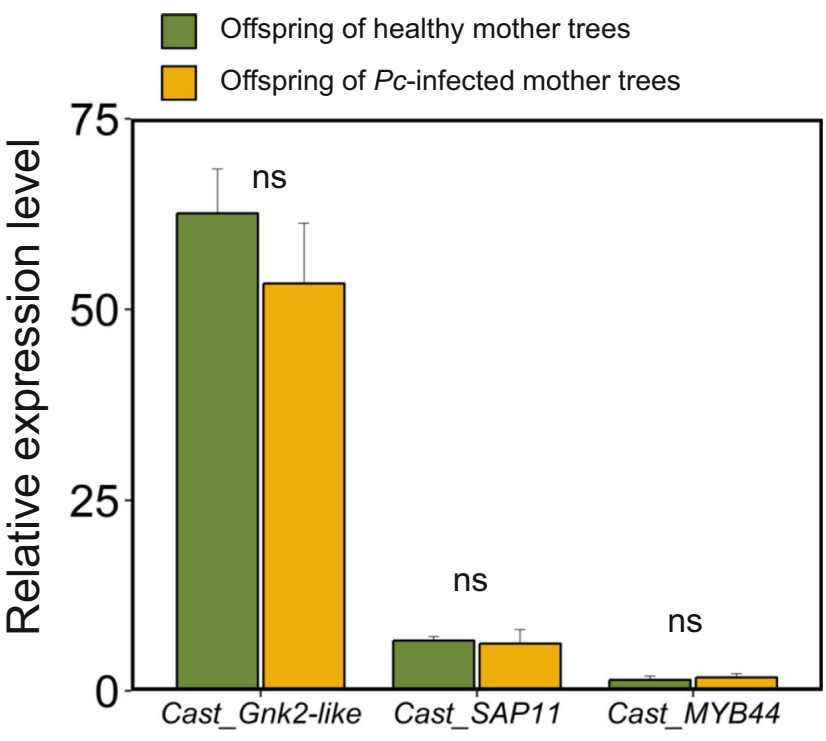

Fig. 5 Relative expression of Cast_Gnk2-like, Cast_SAP11 and Cast MYB44 genes in offspring of healthy and Phytophthora cinnamomi $(P c)$-infected Castanea sativa trees ( $n=3$ plants). Ns indicates nonsignificant differences between means

establishment. This is in agreement with the existence of seed resource-dependent thresholds which, once exceeded, strongly limit phenotypic plasticity within a progeny (Kleunen and Fischer 2005).

\subsection{Similar tolerance to water stress in offspring of chestnuts irrespective of the health status of mother trees}

Seedlings of ink-diseased trees wilted similar to seedlings of healthy trees, and gene expression analysis was consistent with this result. In consequence, $P$. cinnamomi infection in C. sativa does not contribute to the inheritance of dehydration stress memory. Stress memory may increase a plant's survival chances by improving its tolerance abilities and may provide a mechanism for adaptation (Avramova 2019). Priming with mild drought during the flowering stage was shown to be effective in reducing the impact of subsequent severe terminal drought stress in Oryza sativa (Bahuguna et al. 2018). Drought priming in parental plants was recently reported to induce drought tolerance in offspring (Wang et al. 2018; Vivas et al. 2019). In our study, the reduced root water uptake capacity often associated to ink disease (Maurel et al. 2001; Dinis et al. 2011; Camisón et al. 2019) combined with the low precipitation in 2015 at the seed collection site were not enough to induce drought-priming in offspring of $C$. sativa.

The role of 'seed weight' and 'plant height' mediating tolerance to water stress can be explained by the higher root biomass and thus higher water uptake ability in taller plants germinating from the heavier seeds (Ramírez-Valiente et al. 2009; Cubera et al. 2012). Interestingly, leaf mass per area was lower in offspring of P. cinnamomi-infected than of healthy 
trees (Table 2). Low leaf mass per area (or high specific leaf area) is usually associated to species with low tolerance to drought, which produce 'cheap' leaves as long as the season is favorable (Lopez-Iglesias et al. 2014).

\subsection{Increased tolerance to $P$. cinnamomi in small seedlings from ink-diseased chestnuts}

Candidate gene expression patterns in response to $P$. cinnamomi were similar in offspring of healthy and P. cinnamomi-infected trees. However, small plants from P. cinnamomi-infected mother trees showed increased tolerance to further infection by P. cinnamomi, irrespective of seed weight. A recent study reported reduced and delayed mortality of $Q$. ilex seedlings if less virulent Phytophthora species were inoculated before more virulent Phytophthora species (Corcobado et al. 2017). Small chestnuts plants could have been primed for resistance (Ashraf et al. 2018), probably by elicitins and effector molecules released by P. cinnamomi during root infection (Osswald et al. 2014), but this needs further investigation. Active adaptive plasticity of plants in response to the environment requires a specific signal perception-transduction system that moulds plant development and influences next generations (Kleunen and Fischer 2005; Mauch-Mani et al. 2017). Infection by P. cinnamomi in C. sativa is perceived via pathogen recognition proteins that are coded by several defence genes (Santos et al. 2017). After recognition, transcriptional reprogramming in the host may directly provide the tree with pathogen-specific cues that may be transmitted to seeds, resulting in transgenerational phenotypic plasticity in offspring.

Chestnut seedlings that invested fewer resources in growth and attained less biomass died later than their taller counterparts. This was consistently observed through Pearson's correlation, Cox proportional hazards model and survival analyses, and could suggest a growth-defence trade-off that occurred only in offspring of $P$. cinnamomi-infected mother trees. This trade-off is in agreement with ecological theories on plant defence, e.g. the resource availability hypothesis (RAH) and the growth development balance hypothesis (GDBH), which indicate that plant defences involve growth costs, especially in resourcelimited environments (Ferrenberg et al. 2015; Moreira et al. 2015). We did not assess fitness in offspring but morphological traits related to competitive abilities of plants (Younginger et al. 2017) and 'survival' of plants to two different stresses. Studies that use close proxies to fitness (e.g. survival) are expected to show stronger effect sizes than studies using simplistic single traits (Uller et al. 2013).

Several circumstances suggest that the three P. cinnamomiinfected mother trees used were not tolerant to ink disease: (i) there is no evidence of $C$. mollissima and $C$. crenata germplasm in Hervás forest, in contrast to other forests in northern Spain (Alcaide et al. 2020) in which genes from Asiatic germplasm confer resistance to $P$. cinnamomi in offspring; (ii) inoculation with $P$. cinnamomi of progenies from 16 additional mother trees, selected in Hervás at random, resulted in circa $100 \%$ of seedling mortality (Alcaide et al. 2020); and (iii) in spring 2019, tree 4 was almost dead and tree 6 was dead.

Table 2 shows relevant heterogeneity in mean height of the six progenies used, and when assessing adaptive plasticity in offspring, it may occur that seedling height could be confounded with parent effects. However, 'plant height' was included as a covariate in the linear mixed and Cox models. When addressing differences in survivorship between short and tall seedlings, only offspring of trees 5 and 6 contributed to these differences. Offspring of tree 4 did not significantly contribute to differences in survivorship between short and tall seedlings probably because plants were homogeneous in height (standard error was 0.2 vs 0.5 and 0.6 in offspring of trees 5 and 6 , respectively), and probably because tree 4 was severely damaged by P. cinnamomi. Tree 4 had the highest branch dieback and the lowest leaf mass per area values of all $P c$-infected trees, and their nuts were stunted probably as a consequence of severe ink disease damage (Phillips and Burdekin 1982). A hypothetical schematic diagram of what may have occurred in offspring of C. sativa trees is represented in Fig. 6. Nuts from trees 1, 2 and 3 were not primed, small-size offspring of trees 5 and 6 showed increased tolerance to P. cinnamomi at a cost of plant growth, and offspring of tree 4 exceed the threshold for a beneficial effect of priming as a consequence of intense damage.

More mother trees and more tree species should be used to confirm hypothetical Fig. 6. Moreover, in this study, the use of more mother trees or clonally replicated material would have properly allowed distinguishing heritable genetic variation from maternal environmental effects. Unfortunately, seedlings used for gene expression analysis were tall in height, which could explain the lack of differences of gene expression between offspring of healthy and P. cinnamomi-infected trees. Further studies on gene expression patterns would require consideration of plant size. The use of a single and highly virulent isolate of $P$. cinnamomi also limits the conclusions that can be derived from our work. Further studies on maternal effects would require the use of several isolates including some of low virulence in order to capture greater sensitivity from the offspring.

\subsection{Ecological consequences}

How can previous findings betransferred to $C$. sativa forests? In forests where $P$. cinnamomi is absent, $C$. sativa is able to regenerate and reach the main canopy under closed overstories (Camisón et al. 2015; Silla et al. 2018). Our findings suggest that in Phytophthora-infested sites, C. sativa trees will generate small seeds whose viability is not affected by the health status of mother trees. Small seeds are usually associated with early emergence (Solla et al. 2011; $P c$-infected mother tree 1), giving the added advantage of seeds being less exposed to soil-borne 
Fig. 6 Conceptual diagram of circumstances occurring in offspring of Castanea sativa trees after maternal priming (stimulus) or damage caused in nuts by Phytophthora cinnamomi

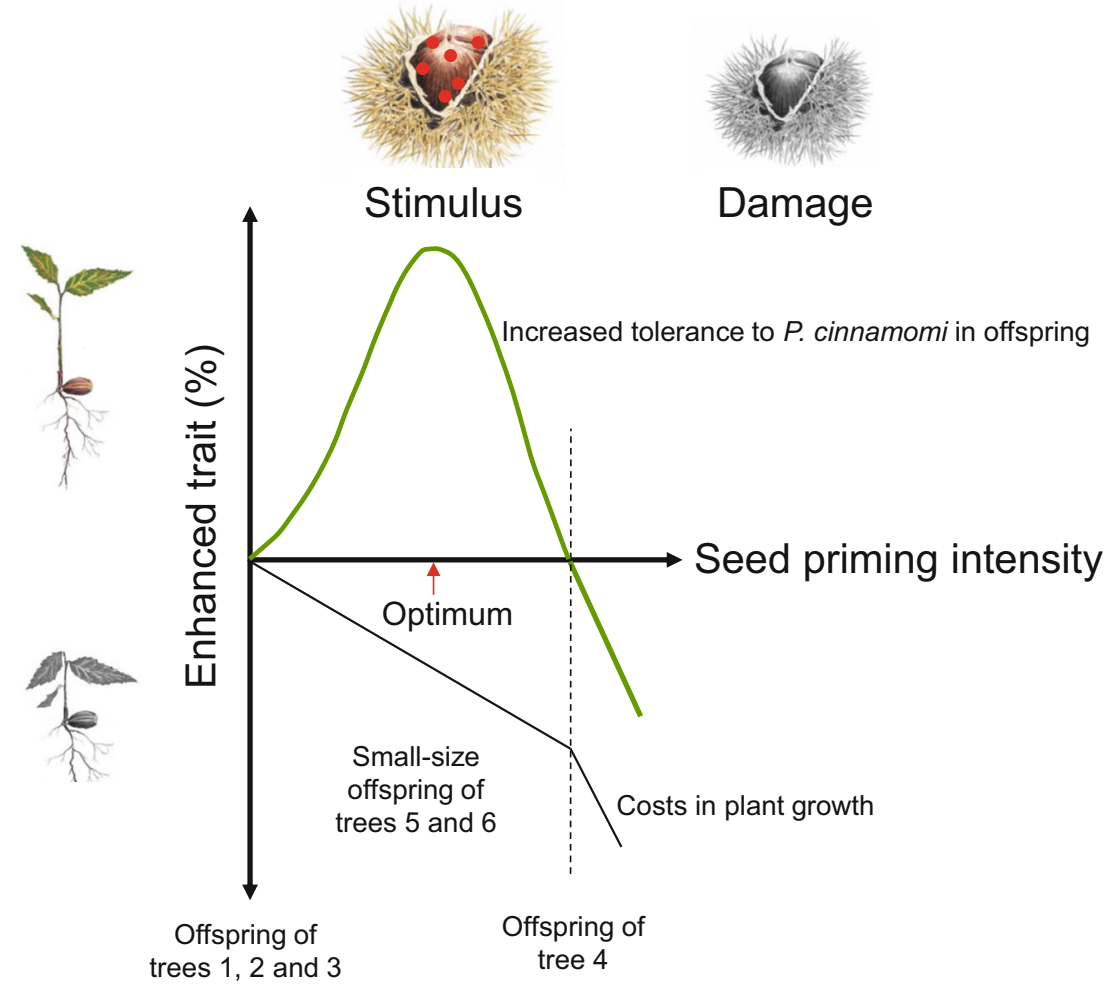

pathogens like Phytophthora spp. (Martín-García et al. 2015). In Phytophthora-infested sites, sexual regeneration may be dominated by small-sized primed seedlings, which respond better than larger conspecifics to P. cinnamomi in the short term. However, small-sized $C$. sativa seedlings will not maintain their competitive ability over other forest species, because of reduced access to light, water and nutrients. Small-sized C. sativa seedlings with fine roots partially killed by $P$. cinnamomi will probably not survive summer drought unless they are able to develop a deep tap root for vertical water exploration. Previous assumptions should be taken with caution for $C$. sativa and validated by long-term assessment of seedlings (from healthy and ink-diseased mother trees) grown in the field.

\section{Conclusion}

Offspring of ink-diseased chestnut trees had poorer performance in plant height and root biomass than offspring of healthy chestnut trees. This effect was probably mediated by seed size-dependent mechanisms involving seed provisioning. Phytophthora cinnamomi infection in chestnut did not contribute to the inheritance of dehydration stress memory. However, small plants of offspring of ink-diseased mother trees showed increased tolerance to $P$. cinnamomi. Increased tolerance was not mediated by seed size and was probably a consequence of seed priming during fruit development. The results suggest that the impact of $P$. cinnamomi on $C$. sativa forests may generate conflicting selection pressures related to plant size, constraining regeneration success at the seedling stage.

Acknowledgements The authors are grateful to José Miguel Sillero and Ester Vega for assistance during field sampling, Francisco de Dios, Francisco Javier Dorado and Francisco Alcaide for technical assistance during plant assessment, and Jane McGrath for English editing of the manuscript. They also thank Dr. Santiago Catalá and Dr. Paloma AbadCampos (Polytechnic University of Valencia) for soil sampling and confirming the presence/absence of Phytophthora cinnamomi under the chestnut trees, and Dr. Susana Serrazina, Dr. Rita Costa and Dr. Carmen Santos for the help in selecting the study genes.

Funding This work was funded by the Spanish Ministry of Economy and Competitiveness [AGL2014-53822-C2-1-R] and the European Union's European Regional Development Fund (ERDF) 'A way to achieve Europe' and the Government of Extremadura (Ref. GR18193). MAM Martín is grateful to the Secretaría General de Ciencia, Tecnología e Innovación, Regional Government of Extremadura (Spain), for financial assistance ('Atracción de Talento Investigador' Programme). JO was supported by a 'Ramon y Cajal' fellowship (RYC-2015-17459).

Data availability Data are available upon request to the corresponding author.

\section{Compliance with ethical standards}

Conflict of interest The authors declare that they have no conflicts of interest. 


\section{References}

Alcaide F, Solla A, Mattioni C, Castellana S, Martín MÁ (2019) Adaptive diversity and drought tolerance in Castanea sativa assessed through EST-SSR genic markers. Forestry 92:287-296

Ashraf MA, Akbar A, Askari SH, Iqbal M, Rasheed R, Hussain I (2018) Recent advances in abiotic stress tolerance of plants through chemical priming: an overview. In: Rakshit A, Singh HB (eds) Advances in seed priming. Springer, Singapore, pp 51-79

Avramova Z (2019) Defence-related priming and responses to recurring drought: two manifestations of plant transcriptional memory mediated by the ABA and JA signalling pathways. Plant Cell Environ 42: 983-997

Alcaide F, Solla A, Cherubini M, Mattioni C, Cuenca B, Camisón Á, Martín MÁ (2020) Adaptive evolution of chestnut forests to the impact of ink disease in Spain. J Syst Evol 58 doi: 10.1111/ jse. 12551

Bahuguna RN, Tamilselvan A, Muthurajan R, Solis CA, Jagadish SVK (2018) Mild preflowering drought priming improves stress defences, assimilation and sink strength in rice under severe terminal drought. Funct Plant Biol 45:827-839

Camisón Á, Miguel R, Marcos JL, Revilla J, Tardáguila MÁ, Hernández D, Lakicevic M, Jovellar LC, Silla F (2015) Regeneration dynamics of Quercus pyrenaica Willd. in the Central System (Spain). For Ecol Manag 343:42-52

Chang S, Puryear J, Cairney J (1993) A simple and efficient method for isolating RNA from pine trees. Plant Mol Biol Report 11:113-116

Ciordia M, Feito I, Pereira-Lorenzo S, Fernández A, Majada J (2012) Adaptive diversity in Castanea sativa Mill. half-sib progenies in response to drought stress. Environ Exp Bot 78:56-63

Conedera M, Tinner W, Krebs P, de Rigo D, Caudullo G (2016) Castanea sativa in Europe: distribution, habitat, usage and threats. In: SanMiguel-Ayanz J, de Rigo D, Caudullo G, Houston Durrant T, Mauri A (eds) European atlas of forest tree species. Publ. Off. EU, Luxembourg, pp 78-79

Corcobado T, Solla A, Madeira MA, Moreno G (2013) Combined effects of soil properties and Phytophthora cinnamomi infections on Quercus ilex decline. Plant Soil 373:403-413

Corcobado T, Miranda-Torres JJ, Martín-García J, Jung T, Solla A (2017) Early survival of Quercus ilex subspecies from different populations after infections and co-infections by multiple Phytophthora species. Plant Pathol 66:792-804

Cubera E, Moreno G, Solla A, Madeira M (2012) Root system of Quercus suber L. seedlings in response to herbaceous competition and different watering and fertilisation regimes. Agrofor Syst 85: 205-214

Cuestas MI, Mattioni C, Martín LM, Vargas-Osuna E, Cherubini M, Martín MA (2017) Functional genetic diversity of chestnut (Castanea sativa Mill.) populations from southern Spain. For Syst 26:eSC06

Camisón A, Martín MÁ, Sánchez-Bel P, Flors V, Alcaide F, Morcuende D, Pinto G, Solla A (2019) Hormone and secondary metabolite profiling in chestnut during susceptible and resistant interactions with Phytophthora cinnamomi. J Plant Physiol 241:153030

Camisón A, Martín MÁ, Dorado FJ, Moreno G, Solla A (2020) Changes in carbohydrates induced by drought and waterlogging in Castanea sativa. Trees doi: 10.1007/s00468-019-01939-x

Çiçek E, Tilki F (2007) Seed size effects on germination, survival and seedling growth of Castanea sativa Mill. J Biol Sci 7:438-441

D’Urso A, Brickner JH (2017) Epigenetic transcriptional memory. Curr Genet 63:435-439

Dewan S, Vander Mijnsbrugge K, De Frenne P, Steenackers M, Michiels $B$, Verheyen K (2018) Maternal temperature during seed maturation affects seed germination and timing of bud set in seedlings of European black poplar. For Ecol Manag 410:126-135
Dinis LT, Peixoto F, Zhang C, Martins L, Costa R, Gomes-Laranjo J (2011) Physiological and biochemical changes in resistant and sensitive chestnut (Castanea) plantlets after inoculation with Phytophthora cinnamomi. Physiol Mol Plant Pathol 75:146-156

Ferrenberg S, Kane JM, Langenhan JM (2015) To grow or defend? Pine seedlings grow less but induce more defences when a key resource is limited. Tree Physiol 35:107-111

Gonthier P, Nicolotti G (Eds.) (2013). Infectious forest diseases. Cabi, Oxfordshire, UK

Ho DH (2014) Transgenerational epigenetics: the role of maternal effects in cardiovascular development. Integr Comp Biol 54:43-51

Jung T, Blaschke H, Neumann P (1996) Isolation, identification and pathogenicity of Phytophthora species from declining oak stands. Eur J For Pathol 26:253-272

Jung T, Pérez-Sierra A, Durán A, Jung MH, Balci Y, Scanu B (2018) Canker and decline diseases caused by soil-and airborne Phytophthora species in forests and woodlands. Persoonia 40: $182-220$

Kassambara A, Kosinski M (2017) Survminer: drawing survival curves using 'ggplot2'. R Package Version 0.4.0.999. R Foundation for Statistical Computing, Vienna, Austria. https://www.sthda.com/ english/rpkgs/survminer/

Kleunen M, Fischer M (2005) Constraints on the evolution of adaptive phenotypic plasticity in plants. New Phytol 166:49-60

Livak KJ, Schmittgen TD (2001) Analysis of relative gene expression data using real-time quantitative PCR and the $2^{-\Delta \Delta C t}$ method. Methods 25:402-408

Lopez-Iglesias B, Villar R, Poorter L (2014) Functional traits predict drought performance and distribution of Mediterranean woody species. Acta Oecol 56:10-18

Marshall DJ, Uller T (2007) When is a maternal effect adaptive? Oikos 116:1957-1963

Martin MA, Mattioni C, Cherubini M, Taurchini D, Villani F (2010) Genetic diversity in European chestnut populations by means of genomic and genic microsatellite markers. Tree Genet Genomes 6: 735-744

Martín MA, Monedero E, Martín LM (2017) Genetic monitoring of traditional chestnut orchards reveals a complex genetic structure. Ann For Sci 74:15

Martín-García J, Solla A, Corcobado T, Siasou E, Woodward S (2015) Influence of temperature on germination of Quercus ilex in Phytophthora cinnamomi, P. gonapodyides, P. quercina and P. psychrophila infested soils. For Pathol 45:215-223

Mauch-Mani B, Baccelli I, Luna E, Flors V (2017) Defense priming: an adaptive part of induced resistance. Annu Rev Plant Biol 68:485512

Maurel M, Robin C, Capdevielle X, Loustau D, Desprez-Loustau ML (2001) Effects of variable root damage caused by Phytophthora cinnamomi on water relations of chestnut saplings. Ann For Sci 58:639-651

Mora-Sala B, Berbegal M, Abad-Campos P (2018) The use of qPCR reveals a high frequency of Phytophthora quercina in two Spanish holm oak areas. Forests 9:697

Moreira X, Zas R, Solla A, Sampedro L (2015) Differentiation of persistent anatomical defensive structures is costly and determined by nutrient availability and genetic growth-defence constraints. Tree Physiol 35:112-123

Osswald W, Fleischmann F, Rigling D et al (2014) Strategies of attack and defence in woody plant-Phytophthora interactions. For Pathol 44:169-190

Phillips DH, Burdekin DA (1982) Diseases of sweet chestnut (Castanea spp.). In: Phillips DH, Burdekin DA (eds) Diseases of forest and ornamental trees. Palgrave Macmillan, London, pp. 273-283

Pliura A, Eriksson G (2002) Genetic variation in juvenile height and biomass of open-pollinated families of six Castanea sativa Mill. 
populations in a $2 \times 2$ factorial temperature $\mathrm{x}$ watering experiment. Silvae Genet 51:152-160

Pazianoto LHR, Solla A, Ferreira V (2019) Leaf litter decomposition of sweet chestnut is affected more by oomycte infection of trees than by water temperature. Fungal Ecol 41:269-278

Ramírez-Valiente JA, Valladares F, Gil L, Aranda I (2009) Population differences in juvenile survival under increasing drought are mediated by seed size in cork oak (Quercus suber L.). For Ecol Manag 257:1676-1683

Redondo MÁ, Pérez-Sierra A, Abad-Campos P, Torres L, Solla A, ReigArmiñana J, García-Breijo F (2015) Histology of Quercus ilex roots during infection by Phytophthora cinnamomi. Trees 29:1943-1957

Robin C, Morel O, Vettraino AM, Perlerou C, Diamandis S, Vannini A (2006) Genetic variation in susceptibility to Phytophthora cambivora in European chestnut (Castanea sativa). For Ecol Manag 226:199-207

Santos C, Machado H, Correia I, Gomes F, Gomes-Laranjo J, Costa R (2015) Phenotyping Castanea hybrids for Phytophthora cinnamomi resistance. Plant Pathol 64:901-910

Santos C, Duarte S, Tedesco S, Fevereiro P, Costa RL (2017) Expression profiling of Castanea genes during resistant and susceptible interactions with the oomycete pathogen Phytophthora cinnamomi reveal possible mechanisms of immunity. Front Plant Sci 8:515

Schneider CA, Rasband WS, Eliceiri KW (2012) NIH image to ImageJ: 25 years of image analysis. Nat Methods 9:671

Serrazina S, Santos C, Machado H, Pesquita C, Vicentini R, Pais MS, Sebastiana M, Costa R (2015) Castanea root transcriptome in response to Phytophthora cinnamomi challenge. Tree Genet Genomes 11:1-19

Shi W, Villar-Salvador P, Li G, Jiang X (2019) Acorn size is more important than nursery fertilization for outplanting performance of Quercus variabilis container seedlings. Ann For Sci 76:22

Silla F, Camisón A, Solana A, Hernández H, Ríos G, Cabrera M, López D, Morera A (2018) Does the persistence of sweet chestnut depend on cultural inputs? Regeneration, recruitment, and mortality in Quercus- and Castanea-dominated forests. Ann For Sci 75:95

Solla A, Aguín O, Cubera E, Sampedro L, Mansilla JP, Zas R (2011) Survival time analysis of Pinus pinaster inoculated with Armillaria ostoyae: genetic variation and relevance of seed and root traits. Eur J Plant Pathol 130:477-488
Soylu A, Eris A, Özgür M, Dalkiliç Z (1999) Researches on the rootstock potentiality of chestnut types (Castanea sativa Mill.) grown in Marmara region. Acta Hortic 494:213-222

Therneau T (2015) A package for survival analysis in S. version 2.38

Uller T, Nakagawa S, English S (2013) Weak evidence for anticipatory parental effects in plants and animals. J Evol Biol 26:2161-2170

Untergasser A, Cutcutache I, Koressaar T, Ye J, Faircloth BC, Remm M, Rozen SG (2012) Primer3-new capabilities and interfaces. Nucleic Acids Res 40(15):e115

Vettraino AM, Morel O, Perlerou C, Robin C, Diamandis S, Vannini A (2005) Occurrence and distribution of Phytophthora species in European chestnut stands, and their association with ink disease and crown decline. Eur J Plant Pathol 111:169-180

Villar-Salvador P, Peñuelas JL, Jacobs DF (2012) Nitrogen nutrition and drought hardening exert opposite effects on the stress tolerance of Pinus pinea L. seedlings. Tree Physiol 33:221-232

Vivas M, Zas R, Sampedro L, Solla A (2013) Environmental maternal effects mediate the resistance of maritime pine to biotic stress. PLoS One 8:e70148

Vivas M, Nunes C, Coimbra MA, Solla A (2014a) Antioxidant activity of Pinus pinaster infected with Fusarium circinatum is influenced by maternal effects. Forest Pathol 44:337-340

Vivas M, Nunes C, Coimbra MA, Solla A (2014b) Maternal effects and carbohydrate changes of Pinus pinaster after inoculation with Fusarium circinatum. Trees 28:373-379

Vivas M, Rolo V, Wingfield MJ, Slippers B (2019) Maternal environment regulates morphological and physiological traits in Eucalyptus grandis. For Ecol Manag 432:631-636

Wang X, Zhang X, Chen J, Wang X, Cai J, Zhou Q, Dai T, Cao W, Jiang D (2018) Parental drought-priming enhances tolerance to postanthesis drought in offspring of wheat. Front Plant Sci 9:261

Younginger BS, Sirová D, Cruzan MB, Ballhorn DJ (2017) Is biomass a reliable estimate of plant fitness? Appl Plant Sci 5:1600094

Zas R, Cendán C, Sampedro L (2013) Mediation of seed provisioning in the transmission of environmental maternal effects in maritime pine (Pinus pinaster Aiton). Heredity 111:248-255

Zhang Z (2016) Semi-parametric regression model for survival data: graphical visualization with R. Ann Transl Med 4:461

Publisher's note Springer Nature remains neutral with regard to jurisdictional claims in published maps and institutional affiliations.

\section{Affiliations}

\section{Álvaro Camisón ${ }^{1} \cdot$ M. Ángela Martín ${ }^{2} \cdot$ Jonàs Oliva $^{3,4} \cdot$ Malin Elfstrand $^{5} \cdot$ Alejandro Solla $^{1}$}

1 Institute for Dehesa Research (INDEHESA), Faculty of Forestry, University of Extremadura, Avenida Virgen del Puerto 2, 10600 Plasencia, Spain

2 Escuela Técnica Superior de Ingeniería Agronómica y de Montes, Departamento de Genética, Edificio Gregor Mendel, Campus de Rabanales, Universidad de Córdoba, 14071 Córdoba, Spain
3 Department of Crop and Forest Sciences, University of Lleida, Lleida, Spain

4 Joint Research Unit, Agrotecnio-CTFC, Lleida, Spain

5 Biocentrum, Department of Forest Mycology and Plant Pathology, Swedish University of Agricultural Sciences (SLU), Almas Allé 8, 75007 Uppsala, Sweden 